\title{
MEDIA PEMBELAJARAN CALISTUNG HEWAN BERTEKNOLOGI AUGMENTED REALITY UNTUK MENARIK MINAT BELAJAR ANAK
}

\author{
Tri Afirianto*1, Wibisono Sukmo Wardhono ${ }^{2}$, Billawal Nadipa Pelealu ${ }^{3}$, Muhammad Aminul Akbar ${ }^{4}$ \\ 1,2,3,4 Universitas Brawijaya \\ Email: ${ }^{1}$ tri.afirianto@ub.ac.id, ${ }^{2}$ wibiwardhono@ub.ac.id, ${ }^{3}$ bilawal.pelealu@gmail.com, \\ ${ }^{4}$ muhammad.aminul@ub.ac.id \\ *Penulis Korespondensi
}

(Naskah masuk: 16 Desember 2020, diterima untuk diterbitkan: 22 Maret 2021)

\begin{abstract}
Abstrak
Salah satu perkembangan anak yang perlu diperhatikan adalah perkembangan kognitif. Contoh perkembangan kognitif pada anak usia dini seperti menyebutkan jumlah benda mulai dari satu hingga sepuluh dan merepresentasikan benda dalam bentuk gambar atau tulisan. Kemampuan tersebut dapat diperoleh melalui kegiatan membaca, menulis, dan berhitung (calistung). Calistung bukanlah suatu kemampuan wajib yang dimiliki oleh anak usia dini, namun kemampuan tersebut tetap perlu disampaikan sesuai dengan metode pembelajaran di PAUD/TK, yaitu dengan cara bermain dan belajar. Untuk mempermudah pemahaman anak tentang calistung diperlukan objek yang sering dijumpai oleh anak, sebagai contoh hewan yang sering dijumpai di kebun binatang. Oleh karena itu, pada penelitian ini dikembangkan media pembelajaran calistung dengan objek hewan. Untuk mengetahui tingkat ketertarikan anak dalam mempelajari calistung, media pembelajaran dikembangkan dengan menggunakan teknologi Augmented Reality (AR). Metode pengembangan yang digunakan adalah iterative rapid prototyping. Berdasarkan pengujian media dengan menggunakan fun testing menghasilkan nilai total rata-rata sebesar $85,6 \%$ yang berarti media pembelajaran ini mampu meningkatkan ketertarikan anak dalam mempelajari calistung.
\end{abstract}

Kata kunci: media belajar, calistung, augmented reality, minat belajar, fun testing

\section{ANIMAL CALISTUNG LEARNING MEDIA WITH AUGMENTED REALITY TECHNOLOGY TO ATTRACT CHILDREN'S LEARNING INTEREST}

\begin{abstract}
One of the child's development that needs attention is cognitive development. Examples of cognitive development in early childhood such as mentioning the number of objects ranging from one to ten and representing objects in the form of images or writing. This ability can be obtained through reading, writing and arithmetic (calistung: Indonesian abbreviation) activities. Calistung is not a mandatory ability possessed by early childhood, but the ability still needs to be delivered in accordance with the learning methods in pre-primary school, that is playing and learning. To facilitate children's understanding of calistung, objects that are often encountered by children are needed, for example animals that are often found in zoos. Therefore, this research developed calistung learning media with animal objects. To find out the level of interest of children in learning calistung, learning media was developed using Augmented Reality (AR) technology. The development method used is iterative rapid prototyping. Based on media testing using fun testing produces an average total value of $85.6 \%$, which means this learning media is able to increase children's interest in learning calistung.
\end{abstract}

Keywords: learning media, calistung, augmented reality, interest in learning, fun testing

\section{PENDAHULUAN}

Pertumbuhan dan perkembangan pada masa kanak-kanak sangat penting di dalam kehidupan manusia. Pada masa ini, anak akan menghadapi tugas baru dan memiliki keahlian tertentu. Oleh sebab itu, keberlangsungan proses perkembangan anak sangat perlu untuk diperhatikan, mulai dari perkembangan kognitif, motorik, sensorik, fisik, bahasa, hingga emosionalnya. Perkembangan kognitif seorang anak dilihat dari kemampuan dalam memahami sesuatu.

Chandrawaty (2020) menuturkan bahwa tingkat pencapaian perkembangan kognitif pada anak berusia 4 hingga 6 tahun di antaranya adalah 
mengetahui konsep banyak dan sedikit, membilang banyak benda satu sampai sepuluh, mencocokkan bilangan dengan lambang bilangan, mengenal pola huruf $\mathrm{ABCD}$, serta merepresentasikan berbagai macam benda dalam bentuk gambar atau tulisan. Beberapa stimulasi untuk mendorong perkembangan kognitif pada anak yaitu menghitung bersama-sama, menggambar orang dan binatang, membaca buku sesuai usianya, serta memahami konsep angka. Faktor utama penunjang perkembangan kognitif pada anak usia dini adalah keturunan dan lingkungan. Untuk faktor lingkungan yang paling berperan adalah keluarga dan sekolah.

Sejak pertengahan semester genap tahun akademik 2019/2020 hingga memasuki awal semester gasal tahun akademik 2020/2021, hampir seluruh sekolah di Indonesia meniadakan kegiatan belajar mengajar secara tatap muka dikarenakan adanya pandemi Covid-19. Menurut Nurkholis (2020), dampak pandemi Covid-19 terhadap pendidikan di Indonesia adalah penurunan motivasi belajar bagi peserta didik. Oleh karena itu, untuk meningkatkan motivasi belajar peserta didik perlu adanya fasilitas media pembelajaran yang menarik. Begitu juga pada Pendidikan Anak Usia Dini (PAUD), media pembelajaran yang memiliki konsep bermain dan belajar perlu diterapkan. Hal ini disampaikan oleh Menteri Pendidikan dan Kebudayaan, Nadiem Makarim, bahwa pendidik di lembaga PAUD maupun orang tua harus memahami konsep bermain dan belajar (Maulipaksi, 2019). Terkait kemampuan kognitif pada anak usia dini, Menteri Pendidikan dan Kebudayaan menambahkan bahwa kemampuan membaca, menulis, dan berhitung (calistung) bukan merupakan suatu target utama.

Memang benar bahwa pada anak usia dini (4-6 tahun) tidak diwajibkan untuk dapat membaca dan menulis, karena kemampuan tersebut baru diajarkan di tingkat SD. Anak usia dini masih perlu melakukan aktivitas bermain, sehingga dikhawatirkan jika calistung diberikan pada anak usia dini dapat menghambat perkembangan potensi anak di kemudian hari. Akan tetapi, bentuk pembelajaran calistung pada anak usia dini dapat dilaksanakan dengan mengacu pada karakteristik umum pada TK, yaitu bermain menjadi aktivitas utama (Asiah, 2018; Lutfatulatifah \& Yulianto, 2017). Oleh karena itu, untuk pembelajaran kognitif pada anak dapat dilakukan dengan cara pendekatan informal, seperti membacakan buku cerita sambil melihat gambar dan tulisan yang sedang dibacakan serta bermain tebaktebakan huruf.

Terkait media pembelajaran dengan konsep bermain dan belajar, beberapa peneliti sebelumnya telah mengembangkan media pembelajaran bagi anak usia dini. Penelitian pertama yang dilakukan oleh Sugianto, Novianto, \& Martono (2015) tentang pengenalan binatang dan habitatnya menggunakan android. Penelitian kedua dari Asniati, Pasrahmaya,
\& Fatimah (2016) tentang pengenalan huruf, angka, warna, hewan, dan buah dalam bentuk gambar dan suara sehingga pembelajaran menjadi lebih mudah dan menyenangkan. Berikutnya dari Jayanti, Meilinda, \& Fahriza (2018) menggunakan tampilan yang menarik dan mudah untuk digunakan oleh anak usia dini. Referensi terakhir dari Rahayu \& Fujiati (2018) yang menyampaikan bahwa gim edukasi dapat menarik minat siswa dalam belajar Bahasa Inggris. Tiga dari empat penelitian yang telah disampaikan menggunakan Android sebagai media pembelajaran.

Selain Android dapat digunakan sebagai media pembelajaran, Android juga mampu digunakan untuk teknologi Augmented Reality (AR). Penelitian tentang penggunaan teknologi AR sebagai media belajar anak usia dini telah banyak dilakukan. Gunawan, Pattiasina, \& Trianto (2017) melakukan pengenalan warna objek 3D dengan memanfaatkan teknologi AR. Teknologi AR mampu memanfaatkan perkembangan fisik dan mental anak terhadap pembelajaran kognitif. Selain itu, teknologi AR untuk anak usia dini merupakan alat bantu yang baik dalam proses belajar-mengajar dan pengenalan teknologi baru (Cascales, et. al., 2012; Oranç \& Küntay, 2019). Jamiat \& Othman (2019) menambahkan bahwa pembelajaran pada anak dengan menggunakan aplikasi AR lebih baik dari pada aplikasi umum pada perangkat bergerak.

Salah satu pelajaran terkait pengembangan kognitif di PAUD adalah pengenalan hewan. Markamah, Subiyanto, \& Murnomo (2018) membuat buku hewan AR sebagai alternatif media pembelajaran untuk meningkatkan pengenalan hewan pada anak usia dini. Hasil dari penelitian tersebut adalah nilai kognitif kelompok eksperimen lebih tinggi daripada kelompok kontrol, sehingga, teknologi AR mampu meningkatkan pemahaman kognitif anak usia dini. Akan tetapi, pada penelitian tersebut belum mengetahui apakah AR mampu menarik minat belajar anak usia dini.

Dalam pengembangan media pembelajaran terdapat beberapa metode yang dapat digunakan, salah satunya adalah iterative rapid prototype. Iterative rapid prototype dipilih karena mampu menghasilkan purwarupa dari kertas yang cepat, kemudian purwarupa tersebut bisa segera dimainkan dan dievaluasi jika masih ada kekurangan (Brathwaite \& Schreiber, 2009), sehingga apabila ada perubahan kebutuhan dari pengguna setelah memainkan purwarupa yang sudah dibuat sebelumnya, pengembang dapat memperbaiki purwarupa dengan segera, begitu seterusnya. Jika iterasi perbaikan purwarupa sudah selesai, maka pengembang dapat mengembangkan versi digitalnya sesuai dengan purwarupa pada iterasi terakhir.

Berdasarkan uraian di atas, media pembelajaran yang telah dihasilkan dari penelitian terdahulu lebih fokus kepada peningkatan kemampuan kognitif tanpa memperhitungkan 
tingkat keminatan belajar anak. Oleh karena itu, pada penelitian ini dikembangkan media pembelajaran calistung berteknologi AR dengan harapan tidak hanya untuk meningkatkan kemampuan kognitif anak namun juga menarik minat belajar anak usia dini. Apalagi dengan kondisi pandemi seperti saat ini, pembelajaran yang diberikan kepada anak usia dini harus menarik agar anak tidak mudah merasa bosan dalam belajar. Adapun pengguna dari media pembelajaran ini adalah anak dengan kisaran umur antara 5 hingga 7 tahun.

\section{METODE PENELITIAN}

Metode pengembangan media pembelajaran yang digunakan pada penelitian ini adalah metode iterative rapid prototype dengan sedikit penyesuaian. Adapun metode tersebut dapat dilihat pada Gambar 1.

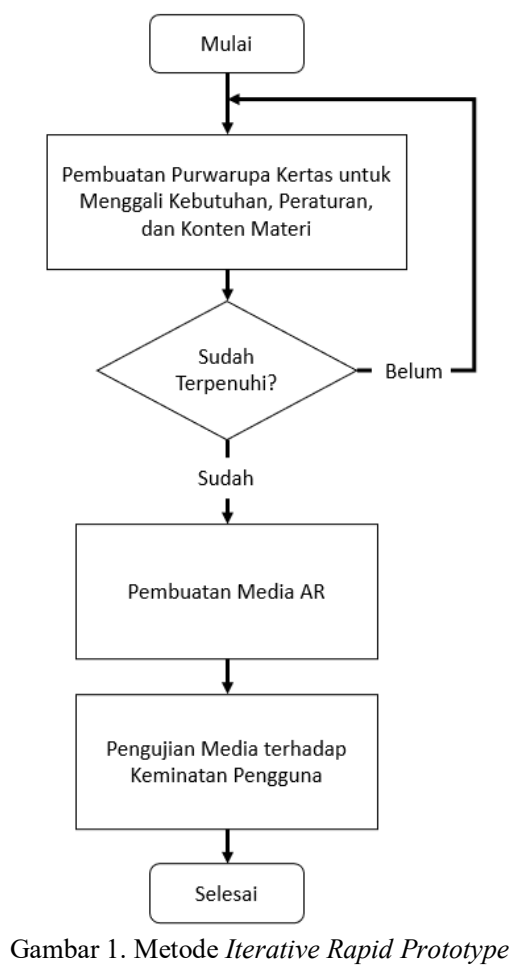

\subsection{Pembuatan Purwarupa Kertas}

Pada tahap awal dilakukan pembuatan purwarupa dari kertas yang dapat dimainkan oleh pengguna dengan menggunakan kartu bergambar hewan, alfabet, angka, dan penghitung waktu. Kebutuhan pertama pada purwarupa kertas iterasi pertama berupa peraturan dan konten materi yang berasal dari peneliti, selanjutnya dilakukan penggalian terhadap perbaikan kebutuhan, baik peraturan maupun konten, berdasarkan masukan dari pengguna. Pengguna purwarupa kertas ini merupakan guru les yang menangani siswa berumur 5 hingga 7 tahun yang bertugas sebagai ahli media. Iterasi terus dilaksanakan apabila peraturan maupun konten belum sesuai dengan karakteristik pembelajaran anak usia dini.

Penentuan aturan dan konten pada iterasi pertama berdasarkan pemahaman penulis terkait calistung, yaitu terdapat dua konten soal (nama hewan dan jumlah hewan). Untuk konten nama hewan, hewan dipilih secara acak berdasarkan lemparan dadu, kemudian pemain menyusun nama hewan berdasarkan huruf-huruf yang sudah disediakan. Pada konten jumlah hewan, sejumlah hewan tertentu ditunjukkan kepada peserta dan peserta menghitung jumlah hewan tersebut. Setelah guru les melakukan percobaan pada purwarupa kertas (Gambar 2 dan Gambar 3), guru les menyatakan bahwa konten yang diberikan masih kurang untuk membuat anak tertarik belajar calistung.

Pada iterasi kedua terdapat penambahan konten soal pencarian hewan berdasarkan timbal balik dari guru les pada iterasi pertama. Nama hewan yang tertulis pada suatu kartu ditunjukkan kepada pemain, lalu pemain mencari hewan berdasarkan isi kartu tersebut. Hasil percobaan dari iterasi kedua terhadap purwarupa kertas pada Gambar 4 adalah kurang adanya penghargaan jika anak berhasil menjawab dan perlu adanya batasan waktu dalam menjawab tiap soal. Berdasarkan evaluasi pada iterasi kedua diperoleh bahwa purwarupa kertas tidak perlu mengalami perubahan namun perlu adanya tambahan peraturan terkait penghargaan dan batasan waktu.

Setelah penambahan peraturan pada iterasi ketiga (Tabel 1), guru les sudah menyetujui dan tidak memberikan evaluasi, sehingga jumlah iterasi pada proses pembuatan purwarupa kertas adalah sebanyak tiga kali. Adapun kebutuhan fungsional berupa peraturan dan konten dapat dilihat pada Tabel 2.

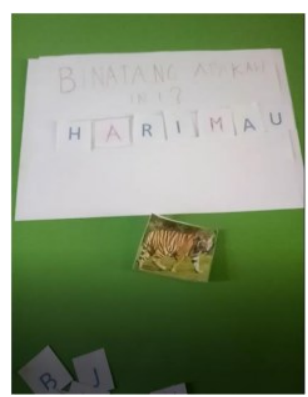

Gambar 2. Purwarupa Kertas Iterasi 1 (Konten Nama Hewan)

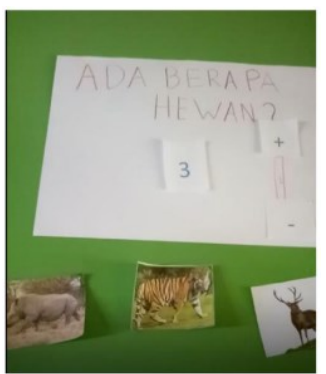

Gambar 3. Purwarupa Kertas Iterasi 1 (Konten Jumlah Hewan) 


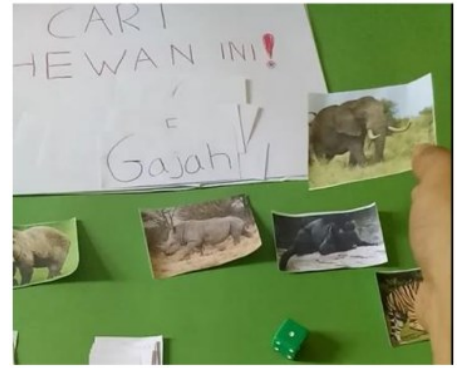

Gambar 4. Purwarupa Kertas Iterasi 2 (Konten Pencarian Hewan)

Tabel 1. Peraturan Durasi dan Penghargaan terhadap Jenis Soal

\begin{tabular}{clcc}
\hline Tingkatan & \multicolumn{1}{c}{ Jenis Soal } & Durasi & Penghargaan \\
\hline 1 & Nama Hewan & 20 detik & +10 \\
2 & Jumlah Hewan & 15 detik & +20 \\
3 & Cari Hewan & 10 detik & +10 \\
\hline
\end{tabular}

\subsection{Pembuatan Media AR}

Setelah peraturan dan konten sudah sesuai dengan ahli media, tahapan selanjutnya adalah pembuatan media pembelajaran berteknologi AR dengan menggunakan penanda. Objek pembelajaran adalah hewan yang sering dijumpai di kebun binatang, yaitu beruang, badak, rusa, gajah, jerapah, babi, dan harimau. Aset 3D hewan yang digunakan dapat dilihat pada Gambar 5 .

Penanda AR berisi beberapa hewan yang digunakan pada Gambar 5 dan dilengkapi dengan motif persegi panjang, kotak, hati, serta bunga. Adapun penanda AR tersebut dapat dilihat pada Gambar 6. Media AR dibuat dengan menggunakan Software Development Kit (SDK) Vuforia dan Unity.

\subsection{Pengujian Media AR}

Langkah terakhir adalah pengujian media pembelajaran terhadap tingkat keminatan anak dalam mempelajari calistung. Adapun pengujiannya menggunakan black box testing, untuk mengetahui validitas kebutuhan fungsional (Nidhra \& Dondeti, 2012), dan fun testing, untuk mengetahui indikasi kesenangan pada anak (Sim, MacFarlane, \& Read, 2006). Pertanyaan pada kuesioner fun testing mengacu pada Soleimani, Green, Herro, Walker, \& Gardner-McCune (2015) dengan jawaban menggunakan 5 skala Likert bertipe Smileyometer untuk memudahkan anak memahami jawaban yang disampaikan. Gambar 7 merupakan contoh pertanyaan dan jawaban dalam bentuk Smileyometer. Tabel 3 merupakan pertanyaan kuesioner yang diberikan kepada responden (anak). Bagi responden yang mengalami kesulitan dalam memahami maksud dari pertanyaan tersebut dibantu oleh guru, kemudian responden mengapresiasikan jawabannya dengan memilih salah satu ekspresi yang ada pada Smileyometer.
Tabel 2. Kebutuhan Fungsional Media Pembelajaran

\begin{tabular}{|c|c|}
\hline Fitur & Hasil yang diharapkan \\
\hline Halaman awal & $\begin{array}{l}\text { Menampilkan gambar latar belakang } \\
\text { dan } 3 \text { tombol (Belajar, Mulai, dan } \\
\text { Keluar) }\end{array}$ \\
\hline Tombol Belajar & $\begin{array}{l}\text { Menuju ke menu belajar nama hewan } \\
\text { dan berhitung }\end{array}$ \\
\hline Mulai & $\begin{array}{l}\text { Menuju ke permainan calistung } \\
\text { dengan } 3 \text { tingkatan }\end{array}$ \\
\hline Keluar & Keluar dari media pembelajaran \\
\hline Belajar nama hewan & $\begin{array}{l}\text { Membaca penanda AR kemudian } \\
\text { menampilkan objek 3D hewan satu- } \\
\text { persatu diikuti dengan tulisan nama } \\
\text { hewan }\end{array}$ \\
\hline Belajar berhitung & $\begin{array}{l}\text { Membaca penanda AR kemudian } \\
\text { menampilkan kandang yang berisi } \\
\text { sejumlah hewan diikuti dengan angka } \\
\text { jumlah hewan pada tiap kandangnya }\end{array}$ \\
\hline \multirow[t]{5}{*}{$\begin{array}{l}\text { Tingkatan } 1 \text { (menulis } \\
\text { ) }\end{array}$} & $\begin{array}{l}\text { a. Menampilkan pertanyaan "HEWAN } \\
\text { APAKAH INI?" disertai dengan } \\
\text { hewan 3D }\end{array}$ \\
\hline & $\begin{array}{l}\text { b. Menampilkan susunan huruf yang } \\
\text { teracak dari nama hewan }\end{array}$ \\
\hline & $\begin{array}{l}\text { c. Menampilkan waktu selama } 20 \text { detik } \\
\text { disertai hitungan mundur untuk } \\
\text { menjawab setiap hewan }\end{array}$ \\
\hline & $\begin{array}{l}\text { d. Jika jawaban benar dan waktu belum } \\
\text { habis, nilai akan bertambah } 10\end{array}$ \\
\hline & $\begin{array}{l}\text { e. Jika pertanyaan atau waktu telah } \\
\text { habis, dapat berpindah ke tingkatan } \\
\text { berikutnya }\end{array}$ \\
\hline \multirow[t]{4}{*}{$\begin{array}{l}\text { Tingkatan } 2 \\
\text { (berhitung) }\end{array}$} & $\begin{array}{l}\text { a. Menampilkan pertanyaan "ADA } \\
\text { BERAPA HEWAN YANG ADA DI } \\
\text { LAYAR?" disertai dengan sejumlah } \\
\text { hewan 3D }\end{array}$ \\
\hline & $\begin{array}{l}\text { b. Mengubah nilai jumlah hewan } \\
\text { dengan menekan tombol + atau - } \\
\text { c. Menampilkan waktu selama } 15 \text { detik } \\
\text { disertai hitungan mundur untuk } \\
\text { menjawab pertanyaan }\end{array}$ \\
\hline & $\begin{array}{l}\text { d. Jika jawaban benar dan waktu belum } \\
\text { habis, nilai akan bertambah } 20\end{array}$ \\
\hline & $\begin{array}{l}\text { e. Jika pertanyaan atau waktu telah } \\
\text { habis, dapat berpindah ke tingkatan } \\
\text { berikutnya }\end{array}$ \\
\hline \multirow[t]{5}{*}{$\begin{array}{l}\text { Tingkatan } 3 \\
\text { (membaca) }\end{array}$} & $\begin{array}{l}\text { a. Menampilkan pertanyaan "CARI } \\
\text { HEWAN [namaHewan]?" disertai } \\
\text { dengan bermacam hewan 3D }\end{array}$ \\
\hline & $\begin{array}{l}\text { b. Mengetahui hewan yang dipilih } \\
\text { berdasarkan sentuhan pengguna }\end{array}$ \\
\hline & $\begin{array}{l}\text { c. Menampilkan waktu selama } 10 \text { detik } \\
\text { disertai hitungan mundur untuk } \\
\text { menjawab pertanyaan }\end{array}$ \\
\hline & $\begin{array}{l}\text { d. Jika jawaban benar dan waktu belum } \\
\text { habis, nilai akan bertambah } 10\end{array}$ \\
\hline & $\begin{array}{l}\text { e. Jika pertanyaan atau waktu telah } \\
\text { habis, menampilkan pilihan } \\
\text { mengulang kembali atau keluar }\end{array}$ \\
\hline
\end{tabular}

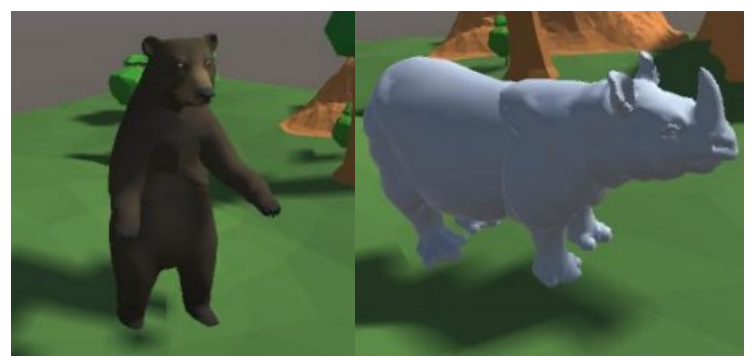




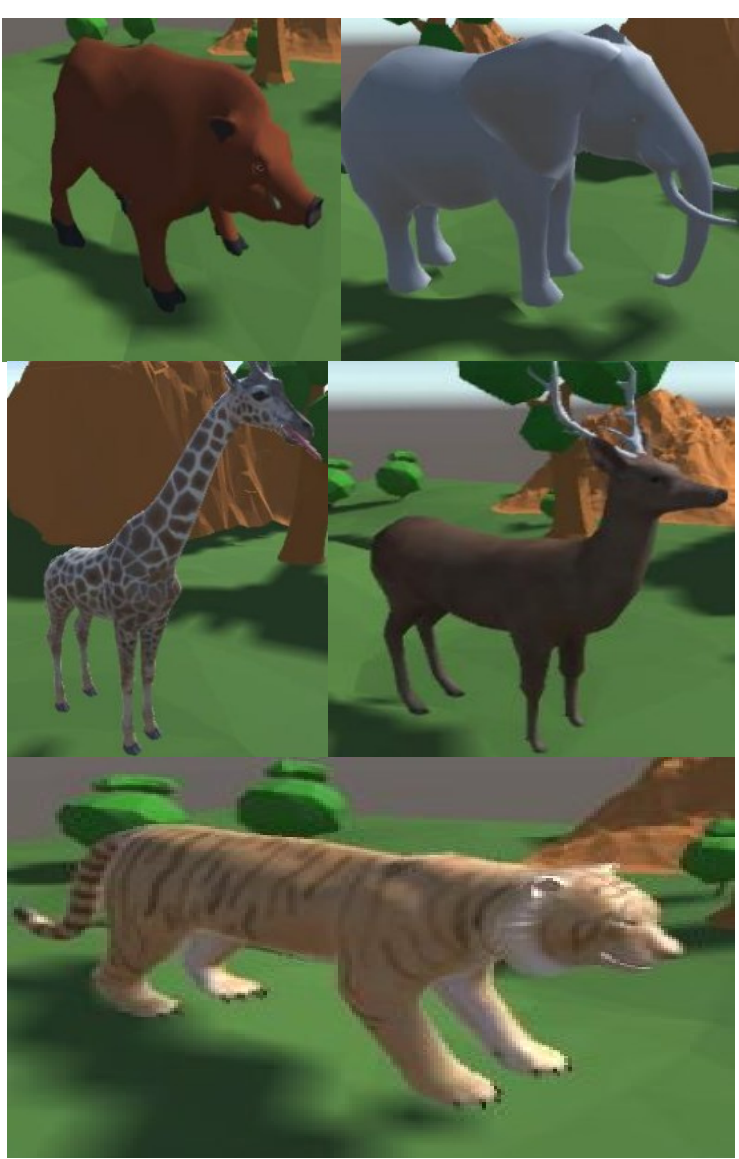

Gambar 5. Aset 3D Hewan

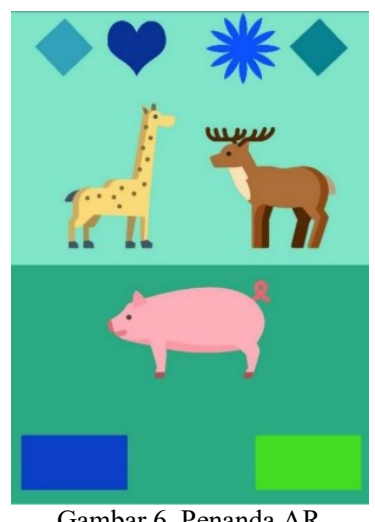

Gambar 6. Penanda AR

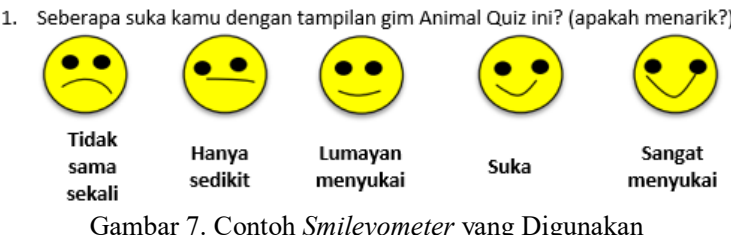

\section{HASIL DAN PEMBAHASAN}

Hasil evaluasi pengujian black box berdasarkan kebutuhan fungsional pada Tabel 2 dapat dilihat pada Tabel 4. Dari Tabel 4 terlihat bahwa seluruh kebutuhan fungsional $100 \%$ berfungsi dan sukses dilakukan.

Untuk hasil evaluasi dari fun testing yang dilakukan terhadap 5 responden anak berusia 5 hingga 7 tahun dapat dilihat rangkumannya pada Tabel 5. Berdasarkan 5 pertanyaan yang telah diberikan, 4 dari 5 pertanyaan menghasilkan nilai di atas 4 dari skala 5 .

Tabel 3. Kuesioner Fun Testing

\begin{tabular}{|c|c|}
\hline $\begin{array}{c}\text { No. } \\
\text { Pertanyaan }\end{array}$ & Pertanyaan \\
\hline 1 & $\begin{array}{l}\text { Seberapa suka kamu dengan tampilan media } \\
\text { pembelajaran Animal Quiz ini? (apakah } \\
\text { menarik?) }\end{array}$ \\
\hline 2 & $\begin{array}{l}\text { Seberapa mudah kamu menggunakan } \\
\text { Augmented Reality untuk memainkan Animal } \\
\text { Quiz? }\end{array}$ \\
\hline 3 & $\begin{array}{l}\text { Seberapa mudah kamu mengenali karakter } \\
\text { hewan yang ada di Animal Quiz? }\end{array}$ \\
\hline 4 & $\begin{array}{l}\text { Seberapa menyenangkan saat kalian memainkan } \\
\text { Animal Quiz? }\end{array}$ \\
\hline 5 & $\begin{array}{l}\text { Seberapa suka kamu dengan teknologi } \\
\text { Augmented Reality? (Apakah menarik?) }\end{array}$ \\
\hline
\end{tabular}

Pertanyaan pertama yang berkaitan dengan tampilan media pembelajaran mendapatkan nilai terendah, yaitu 3,8. Hal ini terjadi karena tampilan media pembelajaran masih sederhana. Meskipun usia responden masih muda, namun mereka berharap tampilan yang disajikan dalam media pembelajaran lebih menarik dengan adanya gerakan animasi dari setiap hewan serta kondisi lingkungan yang menyerupai kebun binatang, sehingga tampilannya seperti di dunia nyata.

Pertanyaan ketiga tentang kemudahan responden mengenali model hewan 3D memiliki nilai paling tinggi $(4,6)$. Dengan adanya kemudahan ini, responden sudah mengetahui nama hewan sehingga tinggal mengetahui susunan huruf apa saja untuk membentuk nama hewan tersebut. Untuk teknologi AR (pertanyaan kelima) mendapatkan nilai 4,2 dan tingkat kemudahan dalam menggunakan media pembelajaran berteknologi AR mendapatkan nilai 4,4. Dampak dari kemudahan responden dalam mengenali model dan nama hewan serta menggunakan media pembelajaran AR mengakibatkan responden merasa senang dengan media pembelajaran ini. Hal ini ditunjukkan berdasarkan nilai dari pertanyaan keempat, yaitu 4,4.

Secara keseluruhan, total nilai rata-rata dari fun testing adalah 4,28 atau 85,6\%. Dari hasil ini dapat disimpulkan bahwa media pembelajaran berteknologi AR yang telah dikembangkan mampu menarik minat anak untuk belajar calistung.

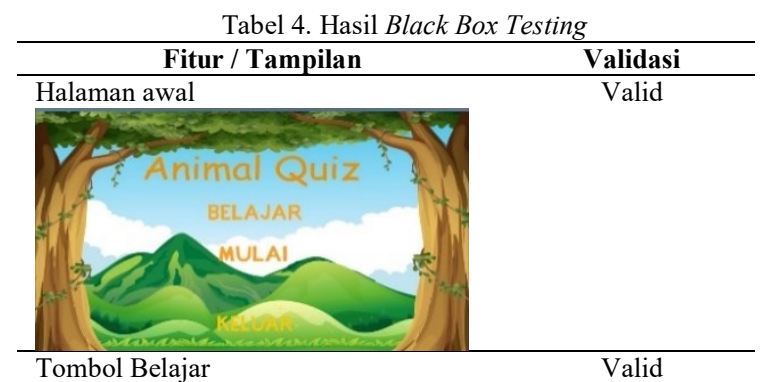




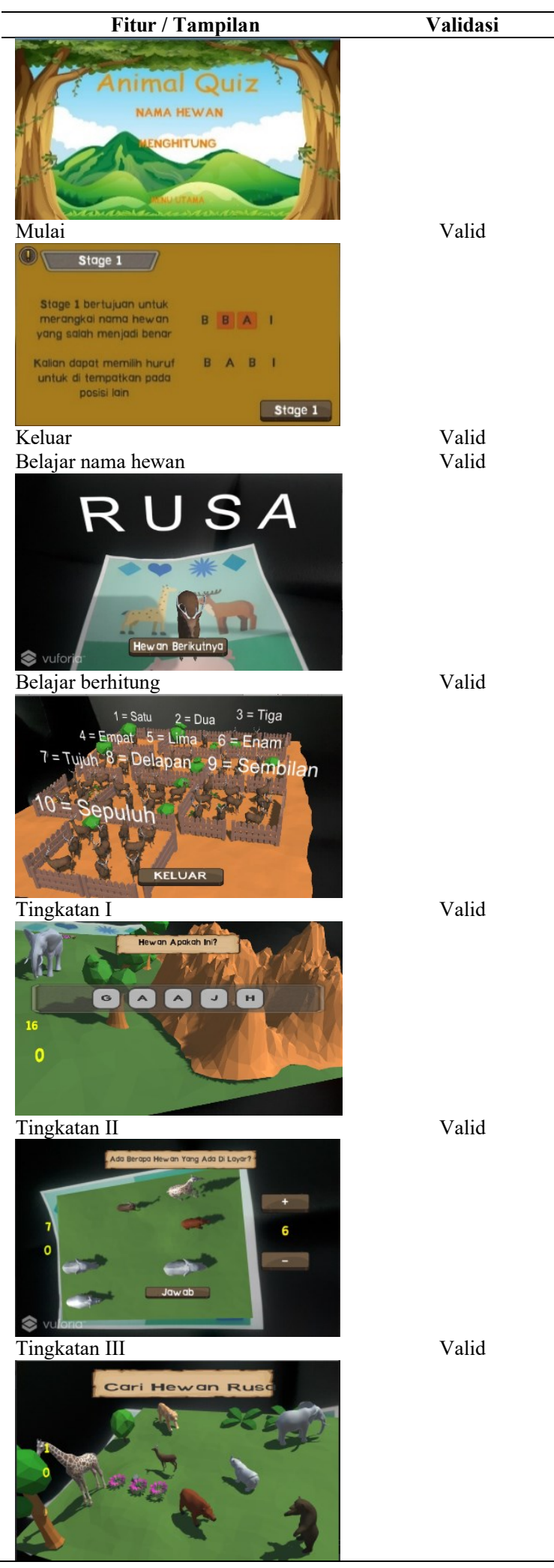

\section{KESIMPULAN}

Pembelajaran terkait membaca, menulis, dan berhitung, atau biasa disebut sebagai calistung, memang tidak wajib diajarkan kepada anak usia dini. Meskipun demikian, pengenalan calistung pada anak usia dini perlu dilakukan namun pengajarannya dilaksanakan dengan cara bermain dan belajar. Untuk mempermudah pemahaman anak dalam membaca dan menulis, maka objek pembelajaran yang digunakan menggunakan hewan yang sering dijumpai di kebun binatang. Selain itu, untuk meningkatkan ketertarikan anak dalam belajar membutuhkan media belajar yang menarik, dalam hal ini media pembelajaran berteknologi AR.

Berdasarkan media pembelajaran yang telah dikembangkan memberikan nilai total rata-rata dari fun testing sebesar 85,6\%. Dengan demikian, media pembelajaran ini diharapkan mampu meningkatkan keterampilan kognitif anak dalam membaca dan menulis. Oleh karena itu, perlu adanya penelitian lebih lanjut tentang tingkat keberhasilan media pembelajaran berteknologi AR dalam meningkatkan kemampuan anak dalam membaca dan menulis.

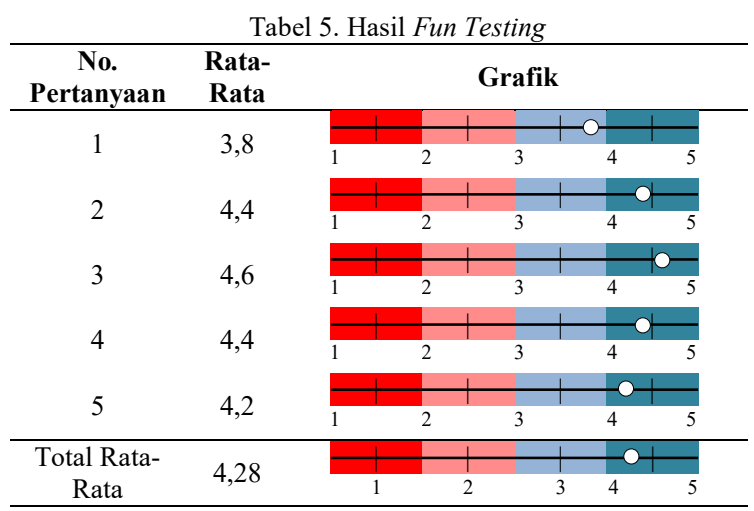

DAFTAR PUSTAKA

ASIAH, N., 2018. Pembelajaran Calistung Pendidikan Anak Usia Dini dan Ujian Masuk Calistung Sekolah Dasar di Bandar Lampung. Terampil: Jurnal Pendidikan dan Pembelajaran Dasar, 5(1), pp.19-42.

ASNIATI, PASRAHMAYA, W. O. H., \& FATIMAH, S., 2016. Aplikasi Edukasi Interaktif Berbasis Android sebagai Media Pembelajaran Pendidikan Anak Usia Dini. Jurnal Informatika Undiayan, 5(1), pp.1-4.

BRATHWAITE, B. \& SCHREIBER, I., 2009. Challenges for Game Designers. Boston: Course Technology.

CASCALES, A., LAGUNA, I., PÉREZ-LÓPEZ, D., PERONA, P., \& CONTERO, M., 2012. Augmented Reality for Preschoolers: an Experience Around Natural Sciences Educational Contents. SPDECE-2012. Alicante: Elsevier's Procedia, pp.113-122.

CHANDRAWATY, dkk., 2020. Pendidikan Anak Usia Dini: Perspektif Dosen PAUD Perguruan Tinggi Muhammadiyah. Tasikmalaya: EDU PUBLISHER.

JAMIAT, N. \& OTHMAN, N. F. N., 2019. Effects of Augmented Reality Mobile Apps on Early Childhood Education Students' Achievement. 2019 The 3rd International 
Conference on Digital Technology in Education. Tsuru: ACM, pp.30-33.

JAYANTI, W. E., MEILINDA, E., \& FAHRIZA, N., 2018. Game Edukasi "Kids Learning" Media Pembelajaran Dasar Untuk Anak Usia Dini Berbasis Android. Jurnal Khatulistiwa Informatika, 6(1), pp.78-86.

GUNAWAN, J., PATTIASINA, T. J., \& TRIANTO, E. M., 2018. Pemanfaatan Augmented Reality sebagai Media Pembelajaran Pengenalan Warna Objek 3D kepada Anak Usia Dini berbasis Android. Teknika, 6(1), pp.47-53.

LUTFATULATIFAH \& YULIANTO, S. W., 2017. Persepsi Guru tentang Membaca, Menulis, dan Berhitung pada Anak Usia Dini. Golden Age: Jurnal Pendidikan Anak Usia Dini, 1(1), pp.77-81.

MARKAMAH, N., SUBIYANTO, \& MURNOMO, A., 2018. The Effectiveness of Augmented Reality App to Improve Students Achievement in Learning Introduction to Animals. Journal of Education and Learning (EduLearn), 12(4), pp.651-657.

MAULIPAKSI, D., 2019. Mendikbud: Pentingnya Konsep Bermain Dan Belajar Di Jenjang PAUD. [online] Kementerian Pendidikan dan Kebudayaan. Tersedia di: $<$ https://www.kemdikbud.go.id/main/blog/2 019/11/mendikbud-pentingnya-konsepbermain-dan-belajar-di-jenjang-paud> [Diakses 10 Juni 2020].

NIDHRA, S. \& DONDETI, J., 2012. Black Box and White Box Testing Techniques - A Literature Review. International Journal of Embedded Systems and Applications (IJESA), 2(2), pp.29-50.

NURKHOLIS, 2020. Dampak Pandemi NovelCorona Virus Disiase (Covid-19) terhadap Psikologi dan Pendidikan Serta Kebijakan Pemerintah. Jurnal PGSD, 6(1), pp.39-49.

ORANÇ, C. \& KÜNTAY, A. C., 2019. Learning From The Real and The Virtual Worlds: Educational Use of Augmented Reality in Early Childhood. International Journal of Child-Computer Interaction, 21, pp.104111.

RAHAYU, S. L. \& FUJIATI, 2018. Penerapan Game Design Document Dalam Perancangan Game Edukasi yang Interaktif untuk Menarik Minat Siswa dalam Belajar Bahasa Inggris. Jurnal Teknologi Informasi dan Ilmu Komputer, 5(3), pp.341-346.

SIM, G., MACFARLANE, S., \& READ, J., 2006. All Work and No Play: Measuring Fun, Usability, and Learning in Software for Children. Computers \& Education, 46(3), pp.235-248.
SOLEIMANI, A., GREEN, K. E., HERRO, D. C., WALKER, I. D., \& GARDNERMCCUNE, C., 2015. CyberPLAYce, A Cyber-Physical-Spatial Storytelling Tool: Results from an Empirical Study with 8-10Year-Old Storytellers. Cham: Springer International Publishing, pp.438-446.

SUGIANTO, NOVIANTO, Y., \& MARTONO, 2015. Perancangan Game Edukasi Pengenalan Binatang dan Habitatnya Berbasis Android (Studi Kasus : TK Ar Ridho Kel.Eka Jaya Jambi). Jurnal Processor, 10(1), pp.436-443. 
Halaman ini sengaja dikosongkan 